\title{
SALMAN RUSHDIE'S SHALIMAR THE CLOWN: A CRITICAL STUDY
}

\author{
Talluri Mathew Bhaskar
}

Lecturer in English

\begin{abstract}
Salman Rushdie's Shalimar the Clown written over a period of four years, deals with Islamic terrorism. It deals with the transformation of a young Muslim boy from a shy teenager to an Islamic terrorist under the guidance of a Muslim mullah. The novel focuses on the trials and tribulations of Shalimar, the protagonist. He is a performer of clownish folk stories who gradually transforms himself into a terrorist. A part of the story originates in the village of Muskadoon in Kashmir. Pachigam, a serene village in Kashmir becomes the centre of destructive activities. A teenaged Muslim boy called Shalimar marries a young girl called Boonyi. Boonyi betrays her husband and falls in love with Maximilian Ophul, a former U.S ambassador to India. They have a child called Kashmira, later rechristened as India. Shalimar determines to take vengeance against his wife, Boonyi and Max and the daughter of his wife. Having killed his wife, Shalimar then sets out to America and kills Max at his daughter India Ophul's house. Shalimar gets military training from Afghani Jihadis - a situation that has been documented in Pakistan in the aftermath of the war between Afghanistan and the Soviet Union. The novel closes on the destruction of entire villages, which correspond to the bouts of ethnic cleansing that prevailed in Kashmir in the 1980s. Shalimar seems to be fighting for a religious cause, but in reality, he uses the religious veil as a platform to kill his wife's lover.
\end{abstract}

Key words: Islamic terrorism, Betrayal, Jihadis, ethnicity.

Salman Rushdie remains a major Indian writer in English. He has been justly labelled by the critics as a postcolonial writer who knows his trade well. As a writer Rushdie is idiosyncratic and individualistic. He wrote Shalimar the Clown in 2005. It has attracted a significant attention. Shalimar the Clown derives its name from Shalimar gardens in the vicinity of Srinagar one of several Mughal Gardens. The novel focuses at the destruction of Kashmir that serves as the backdrop of much of the action in the novel. When Rushdie sat down to write this novel, tears rolled down his cheeks:

I felt very emotional writing this book almost all the way through. There were things happening to me writing this that have never happened to me in my life, bits that made me cry while I was writing it.... It was a very big emotional experience for me. ${ }^{1}$

Shalimar the Clown is Rushdie's ninth novel. It deals with history. He employs postmodernist technique to delineate the theme of borders and borderlessness. In this novel Rushdie voices his concept of borderless world, and its implications:

Everywhere was now a part of everywhere else. Russia, America, London, Kashmir. Our lives, our stories, flowed into one another's, we are no longer our own, individual, discrete. The unsettled people. There were collisions and explosions. The world was no 
longer

calm.

(p.37)

According to postmodernism, the contemporary reality is without borders there by every part of everything else and vice versa. The locale of the novel encompasses parts of the world from America to Kashmir. Pachigam, a small village in Kashmir situated in the serene surroundings beside the river Muskadoon is a quiet, peaceful village. Muskadoon means 'refreshing'. It is in this village that Noman Sher Noman begins his life as Shalimar the Clown. Pachigam, a serene village becomes the centre of destructive activities. Shalimar and Boonyi(Pachigami boy and girl) were madly in love with each other and wanted to get married. Shalimar is a handsome, gentle, gravity-free tight rope walker. Bhoomi is the daughter of Pyarelal Kaul. She exchanges her name to Boonyi. The people in the village called Pachigam live their lives in blissful oblivion only to wake up to the harsh realities of life when insurgency first raised its ugly head in the valley in the form of Kabalis from Pakistan. Shalimar is a son of the village headman. His character is described in glowing terms by the novelist.

How handsome he was, she mused tenderly, how funny in his clowning, how pure in his singing, and partly in her mother's, because she had died there on that night of my disappearances when the world began to change.

(p.50)
He excels in the art of tight rope. The elders of the village, true to the tradition of brotherhood in Kashmir, bless the young couple upholding the values of Kashmiriyat practice. After many hiccups, both sides agreed to the marriage because their love affair was more of love-centred rather than religion-centred in Kashmir. Abdullah Noman and other Panchayat members criticized the licentious behaviour of the couple Boonyi and Shalimar the Clown. Shalimar's father, the village Sarpanch prounounced his judgement:

Abdullah then mentioned
Kashmiriyat, Kashmiriness,
the belief that at the heart of
Kashmiri culture there was a
common bond that transcended
all other differences. Most
bhand villages were Muslim
but Pachigam was a mixture,
with families of pandit
background, the Kauls, the
Misris, and the baritone
singer's long-nosed kin-
.............both Hindu and
Muslim customs will be
observed." Pyarelal added,
when his turn came, "To
defend their love is to defend
what is finest in ourselves."
(p.110)

Pachigam was famous for its traditional entertainment and dance performances of ancient myths and known for the sensible and humourous co-existence of its mixed Hindu and Muslim population. Salman Rushdie is a master story teller. 
In this novel, Rushdie has presented two different worlds: a world of peaceful coexistence and the world of terrorism and extremism. Kashmiri people lived in peace from the times of yore. Both the Hindus and Muslims co-existed in the valley of Kashmir. Compromise and tolerance are the two wheels of human existence. Kashmiri people had tolerance and intercultural common sense of compromise. Pachigam and Shirmal are two rival villages. They solve their disagreements with humour, moderation and common sense. These two villages do not hesitate to bend their ideologies and dogmas to suit their mutual co-operation and friendship. Together the two villages represent a paradise of innocence, peace and tolerance. They are located in the fragrance and fertility of Kashmir, a hidden Garden of Eden. In the beginning of the novel, Salman Rushdie leads us astray with a beautiful evocation of Boonyi's virginal romance in the midnight meadows of Khelmarg. But from then onwards, it is all hatred and terror. Boonyi is far from happiness. Claustrophobia grips her. She realises rather too late that she wants to escape.

She knew then that she would do anything to get out of Pachigam, that she would spend every moment of every day waiting for her chance, and when it came she would not fail to pounce upon it, she would move faster than fortune, that elusive will-o'the-wisp, because if you spotted a magic force-a fairy, a djinni, a piece of once-in-a-

\begin{abstract}
lifetime luck-and if you pinned it to the ground, it would grant you your heart's desire; and she would make her wish, get me away from here, away from my father, away from this slow death and slower life, away from Shalimar the Clown. (pp.114-115)
\end{abstract}

With a hope to grow as a dancer and get exposed to more open an atmosphere, Boonyi wants to leave Pachigam. In her sight it was hell or a prison. After making love to Boonyi for the first time, Shalimar naively uttered words turn prophetic. He said that he would kill her if she left him. Boonyi, besides being bewitchingly beautiful, was courageous too in her love as well as aspirations in life. Shalimar fell in love with her:

Because boonyi's daring was
the single quality he most
admired. He had fallen in love
with her in large part because
she was so seldom afraid,
because she reached out for
what she wanted and grabbed
at it and didn't see why it
should elude her grasp.
(p.93)

Shalimar swears solemnly that if she is ever unfaithful, he will kill her, her lover and their child if there is one. The structure of the whole novel is based on this. Boonyi, being unhappy, decides to wait for a chance to leave Pachigam in search of becoming an accomplished dancer. She is 
on the lookout for an opportunity to dance in a performance for Max Ophul, the American ambassador to India. Things come to a turn when Maximilian comes to the village and becomes enamoured with Boonyi. Rushdie gives a dramatic twist to the narrative by making Max Ophul's (who is American ambassador to India during 1960s) visit Pachigam. Max has been described as scion of a cultured Ashkenazi family, a French Resistance hero, a holocaust survivor and also Marlon Brando's chum. Max falls for Boonyi's physical as well as artistic charm as a dancer. The novelist describes her beauty:

Boonyi Kaul, dark as a secret, bright as happiness. (p.48)

Increasing influence of alien presence on the Kashmiri landscape slowly starts corroding and degrading the values of the valley, Kashmiriyat. This influence is seen in the radical preaching of Bulbul Fakh, the iron mullah; and in the arrival of Max Ophul's on the scene, the representative American presence in the valley. And this unfolds the undesirable events of the story:

... the story of Max and Boonyi's doomed relationship (which) can be read as a study in human vanity, selfishness and aggressive mutual need, but also as a parable of the carelessness of American intervention on the SubContinent. Beware of the written of the repressed, he (Rushdie) seems to be saying, in often unexpected and violent forms. ${ }^{2}$

Maximilian Ophuls is a hero of World War II resistance, master forger, adventurer, intellectual author, poet and seducer. With the help of his assistant, Max gets her (Boonyi) a flat in Delhi, and an affair blooms. Max arranges for Boonyi and her friends to give a dance performance in Delhi. The performance is only a pretext for Max to get close to Boonyi. She had been waiting for this opportunity only. Boonyi chooses to transgress the moral and religious code in search of a future. Max and Boonyi get closer to each other. Though she thought that by her unwise action she had gained release from the village existence that she so detested, yet the stirrings of her heart never lead her escape the Kashmir embedded in her very being, her soul. She could not tear out memories of her valley and her husband, Shalimar the Clown who still loved her. Her attraction started waning. Boonyi became increasingly alienated and depressed. She finds solace in food and drugs:

But her narcotic of choice turned out to be food. At a certain point early in the second year of her liberated captivity, she began, with great seriousness and a capacity for excess learned from the devilcity itself, to eat. Yes, she was a whore, she admitted to herself with a twist of the heart, but she would at least be an 
extremely well-fed one.

(pp.201-202)

Shalimar the Clown learns about his wife treachery with the ambassador. His ideal and romantic is shattered. He finds comfort and soothing by joining the Muslim movement in favour of a free Kashmir. Boonyi's relationship with Max based on infatuation and being superficial begins to wane. Having lost her physical attraction, Boonyi no longer attracts the attention of Max. She becomes addicted to chewing tobacco and opium consumption that provide her means of daydreaming and escape from reality. Max decides to send her back home at a time when Boonyi reveals to him of her being conceived. Their relationship, having assumed the portion of a scandal attracts the attention of the media. After a series of incidents, Max is withdrawn as the American ambassador. His wife makes arrangements for Boonyi's safe delivery of the child. After that Boonyi went back to Pachigam, her village. Now she is a failed woman who realises that her freedom is only an illusion. Boonyi's child is called Kashmira. Later that child is rechristened as India. India is taken away from her mother to Max and his wife. It is Max Ophuls, the Jewish European who destroys the sacred marriage and happiness of Boonyi and Shalimar. When his marital bliss is shattered, Shalimar, harmless, gifted artist of mystic balance, is horrifyingly transformed into Shalimar the assassin and savage avenger. Shalimar's private anger feeds his desire to join Jihad. He soon becomes a model fighter with a single goal in his life: to kill Max who ruined his marital happiness and domestic peace, and to murder his treacherous wife by cutting off her head. He actually enjoys killing. The structure of this novel is based on this point all-consuming hatred. When is taught fundamentalism and Puritanism into terrorist camps along the high mountain borders with Pakistan, he quickly becomes a maniacal assassin. His mind hopelessly poisoned by personal hatred and ideological propaganda. Pachigam becomes home for terrorists. The armed forces use violence against the people of Pachigam. Rushdie says:

There were six hundred thousand Indian troops in Kashmir but the pogrom of the pandit's was not prevented, why was that. Three and a half lakhs of human beings arrived in Jammu as displaced persons and for many months the government did not provide shelters or relief or even register their names, why was that. When the government finally built camps it only allowed for six thousand families to remain in the state, dispersing the others around the country where they would be invisible and impotent, why was that..................to $\operatorname{rot}$ while the army and the insurgency fought over the bloodied and broken valley, to dream of return, to die while dreaming of return, to die after the dream of return died so that they could not even die dreaming of it, why was that why was that why was that 


\section{ELK}

Asia Pacific Journals

why was that why was that. (pp.296-297)

The fight for a religious cause just provides a platform for Shalimar to cross over to the other side to reach his target in America and eliminate him. Knowledge of Max's secret dealings and his views on Kashmir fuels his rage further and gives new life to his ambition. After killing Boonyi ruthlessly in cold blood, he becomes free to pursue his final target. Charged with harbouring extremists Pachigam bears the brunt of the atrocities of the armed forces. Many innocent people are killed. Pachigam ceases to exist. The narrator indicates the pathetic situation of the people of Kashmir who have to bear the cruel acts of both the terrorists as well as the armed forces. According to Roth Marco:

Undone by the twin forces of nationalism and religious fundamentalism, as usual in Rushdie's novels these forces are not enemies of enlightenment as much as they are the enemies of freedom and that means they are the enemies of the natural. ${ }^{3}$

Having killed Boonyi, Shalimar then sets out to America and kills Max at his daughter, India's house. India Ophuls learns that the killer of her parents is none other than her mother's husband, Shalimar. Shalimar uses the religious veil as a platform to kill his wife's paramour. The twist in Shalimar the Clown's revenge is the survival of Kashmira. Having assumed a new name, Kashmira, India Ophuls decides firmly to avenge the murder of her parents. She dedicates her life to the hatred of Shalimar who murdered both her mother and her father. When Shalimar rots in prison awaiting trial for the murder of her parents, she writes him hundreds of poisonous hate-letters. And when Shalimar miraculously escapes from Death Row in San Quentin Prison, Kashmira does not hide in maidenly terror. On the contrary like the Goddess of the hunt, Diana, she takes out her bow and arrows and becomes the huntress lusting to revenge by hunting him down. A fictionalised account of Bugatti Auto mobile Company plays a role in Shalimar's escape. Shalimar reaches America and works as Max's driver for some time. He kills Max on the day he gives his notice. $\mathrm{He}$ is finally presumed killed by Kashmira who avenges her parents' death. But the end of the novel is a cliff hanger. Kashmira is a highly unfeminine parallel. Single-mindedly Kashmira trains daily with her bow and arrows, guns and martial arts. She lives for one purpose only: to kill Shalimar the Clown. The novel begins with a playful tone and rushes erratically along towards the horror of the climax and catastrophe and then reverts to the macabre playfulness of the novels open ending. The characterization is hopelessly inconsistent and the only winner is the evident need of the plot for some sensational twists and turns. The novelist did not hesitate to mix in some earthy humour with high tragedy. Through all his extremes he takes his readers with him to a bizarre, a heartstopping finale. The realisation on the part of Kashmira (India Ophuls) symbolises a 


\section{ELK}

\section{Asia Pacific Journals}

new beginning. She is an embodiment and a symbol of hope and regeneration emerging from betrayal. At a symbolic level, the survival of India (Kashmira) indicates that Kashmir problem will find an amicable and peaceful solution. The novelist is critical of religion as a subterfuge for spreading terrorism. This could be one of the reasons as to why Rushdie is acceptable to the west but rejected by the Islamic countries. Hatred can never extinguish the life force. It lives on the hearts of people, like it does in Kashmira. Kashmira embodies the emergence of a new beginning from the chaos and turmoil of betrayal to the arrival of a bright new dawn, full of hope and regeneration. All divisions dissolve and pave the way for the reign of humanism. The novel reaffirms Rushdie's status as the unmatched biographer of the midnight nation. The novel is an extremely ambitious work in which the personal, the political and ideological are intertwined to create a powerful, but flawed masterpiece.

\section{References}

[1] Downie, Andrew, "Tears of Shalimar the Clown", an interview with Salman Rushdie in The Scotsman (October 27, 2005), www.edinburghfestivals.com/topics.cfm?tid

[2] Cowley, Jason, "From here to Kashmir", Rev. Of Shalimar the Clown. The Guardian weekly, vol.173 No.14 Sept.2005, p.27.

[3] Roth Marco, "Give the people what they want", Review of Shalimar the Clown, The Times Literary Supplement, No.5345, Sept.9,2005, 19. 